\title{
Postoperative first-month biochemical parameters in laparoscopic sleeve gastrectomy patients
}

\author{
๑ Zuhal Karaca Karagöz, ${ }^{1}$ ๑ Burhan Hakan Kanat, ${ }^{2}$ ๑ Nurullah Aksoy, ${ }^{3}$ ๑ Nizamettin Kutluer, \\ ๑ Mehmet Buğra Bozan, ${ }^{4} \odot$ Sinan Irtegün, ${ }^{1} \odot$ Selim Sözen, ${ }^{5} \odot$ Ali Aksu $^{1}$ \\ 'Department of Internal Medicine and Endocrinology, Health Sciences University, Elazığ Fethi Sekin State Hospital, Elazığ, Turkey \\ ${ }^{2}$ Department of General Surgery, Health Sciences University, Health Sciences University, Elazığ Fethi Sekin State Hospital, Elazığ, Turkey \\ ${ }^{3}$ Department of General Surgery, Şanlıurfa Siverek State Hospital, Şanlıurfa, Turkey \\ ${ }^{4}$ Department of General Surgery, Kahramanmaraş Sütçü Imam University Faculty of Medicine, Kahramanmaraş, Turkey \\ ${ }^{5}$ Private General Surgery Clinic, İstanbul, Turkey
}

\begin{abstract}
Introduction: Sleeve gastrectomy (SG), which was first described as a part of the duodenal switch procedure, has become the most commonly used type of metabolic surgery in Turkey and the world. This study is an evaluation of the effects of SG surgery on the levels of glucose metabolism, liver enzymes, and thyroid hormones in the first postoperative month, according to age and gender.
\end{abstract}

Materials and Methods: A total of 124 consecutive patients who underwent SG at a single center between January 2018 and September 2019 were retrospectively evaluated for enrollment. The biochemical parameters of the patients measured at the first postoperative month were evaluated and any differences between female and male patients were analyzed.

Results: Twenty-five patients were excluded from the study due to insufficient data and the study was performed using the records of 99 patients. Of the group, 70 (70.7\%) were female and 29 (29.3\%) were male, with a mean age of $35.42 \pm 11.47$ years (range: 18-68 years). Preoperative alanine aminotransferase (ALT), aspartate aminotransferase (AST), and gamma-glutamyl transferase (GGT) values were found to be significantly higher in male patients $(p<0.05)$. No significant difference was observed between the male and female patients in terms of free-T4 and thyroid-stimulating hormone values, $(p>0.05)$ whereas there was a significant difference between the genders in terms of free-T3 (fT3) thyroid hormone $(p<0.05)$. There was no significant difference between the female and male patients in terms of glucose, glycated hemoglobin (HbA1c), or age.

Conclusion: SG was found not only to have mechanical effects but also to cause many metabolic changes. There are currently too few studies in the literature examining how these metabolic changes alter the biochemical parameters. According to the results of a small number of studies, SG significantly reduces body mass index, and the levels of AST, triglycerides, and HbA1c. The results of this study indicated that AST, ALT, GGT, and fT3 levels were higher in men after SG than in women.

Keywords: Biochemical parameters; laparoscopic sleeve gastrectomy; liver functions; morbid obesity; thyroid functions. 


\section{Introduction}

Obesity is defined as abnormal or excessive fat accumulation associated with serious health problems. Surgical treatment is currently the most effective treatment modality with the highest proven efficacy in the treatment of obesity. Obesity is associated with an increase in the number of comorbidities (e.g. type 2 diabetes, ischemic heart disease, and hypertension).

Sleeve gastrectomy (SG), which was first described as a part of the duodenal switch, has become the most commonly used metabolic surgery type both in Turkey and the world. It has been found that serum ghrelin hormone level decreased, ${ }^{[1]}$ insulin secretion decreased ${ }^{[2]}$ and glucagonlike peptide-1 (GLP-1) levels increased ${ }^{[3]}$ in patients operated with this method. Metabolic changes after SG have not been fully elucidated yet.

In this study, patients who underwent consecutive SG were evaluated and the effects of surgery on glucose metabolism, liver enzymes and thyroid hormone levels in the first postoperative month were analyzed separately according to age and gender.

\section{Materials and Methods}

A total of 124 patients, who were operated consecutively in our clinic between January 2018 - September 2019, were retrospectively evaluated. Biochemical parameters of the patients at the first postoperative month were evaluated and it was investigated whether there was any difference between female and male patients in terms of the parameters. The data were obtained from computer records. Patients who lacked sufficient data were excluded from the study.

Statistical analysis was performed using SPSS version 20.0 software. Independent samples t-test or Mann Whitney $\mathrm{U}$ test were used for numerical values. Categorical data were analyzed by using the chi-square test. The numerical values were expressed as mean \pm standard deviation (minimum - maximum values).

\section{Results}

Twenty-five patients were excluded from the study due to lack of data and the study continued with 99 patients. Of the patients, $70(70.7 \%)$ were female and $29(29.3 \%)$ were male with a mean age of $35.42 \pm 11.47(18-68)$ years. Table 1 presents the laboratory findings of the patients.
Preoperative alanine aminotransferase (ALT), aspartate aminotransferase (AST) and gamma-glutamyl transferase (GGT) values were found to be significantly higher in male patients $(p<0.05)$. No significant difference was observed between the male and female patients in terms of free T4 and thyroid-stimulating hormone (TSH) values $(\mathrm{p}>0.05)$ whereas there was a significant difference between the genders in terms of free T3 from thyroid hormones $(\mathrm{p}<0.05)$. There was no difference between female and male patients in terms of glucose, HbA1c, and age (Table 2).

\section{Discussion}

Sleeve gastrectomy is a bariatric surgery technique, which involves the resection of fundus throughout the world,

Table 1. Biochemical test results of patients participating in the study

\begin{tabular}{lc} 
Parameters & Mean \\
\hline HbA1c $(\%)$ & $6.06 \pm 1.37(4.9-12.4)$ \\
Glucose $(\mathrm{mg} / \mathrm{dL})$ & $116.09 \pm 54.39(68-478)$ \\
AST $(\mathrm{U} / \mathrm{L})$ & $25.01 \pm 15.06(12-123)$ \\
ALT $(\mathrm{U} / \mathrm{L})$ & $33.08 \pm 27.97(8-184)$ \\
GGT $(\mathrm{U} / \mathrm{L})$ & $37.77 \pm 52.79(6-465)$ \\
TSH $(\mathrm{mlU} / \mathrm{L})$ & $1.88 \pm 2.73(0.32-25.52)$ \\
Free T3 $(\mathrm{ng} / \mathrm{L})$ & $3.63 \pm 0.61(0.95-5.39)$ \\
Free T4 (ng/dL) & $0.85 \pm 0.13(0.44-1.23)$ \\
\hline
\end{tabular}

HbA1c: Hemoglobin A1C; AST: Aspartate aminotransferase; ALT: Alanine aminotransferase; GGT: Gamma-glutamyl transferase; TSH: Thyroid-stimulating hormone.

Table 2. Comparison of patient data according to gender

\begin{tabular}{lcc} 
& Male & Female \\
\hline Age & $32.10 \pm 10.84$ & $34.05 \pm 11.52$ \\
HbA1c $(\%)$ & $5.93 \pm 1.67$ & $5.59 \pm 2.07$ \\
Glucose $(\mathrm{mg} / \mathrm{dL})$ & $111.30 \pm 37.61$ & $118.07 \pm 60.11$ \\
AST $(\mathrm{U} / \mathrm{L})$ & $29.11 \pm 11.26^{*}$ & $22.95 \pm 16.28$ \\
ALT $(\mathrm{U} / \mathrm{L})$ & $44.51 \pm 24.64^{*}$ & $28.34 \pm 28.05$ \\
GGT $(\mathrm{U} / \mathrm{L})$ & $43.52 \pm 41.17^{\star}$ & $30.53 \pm 55.00$ \\
TSH $(\mathrm{ulU} / \mathrm{mL})$ & $1.63 \pm 1.36$ & $1.90 \pm 3.10$ \\
free T3 $(\mathrm{pg} / \mathrm{mL})$ & $3.95 \pm 0.35^{\star}$ & $3.24 \pm 0.70$ \\
free T4 $(\mathrm{ng} / \mathrm{dL})$ & $0.88 \pm 0.14$ & $0.79 \pm 0.19$
\end{tabular}

*P<0.05. HbA1c: Hemoglobin A1C; AST: Aspartate aminotransferase; ALT: Alanine aminotransferase; GGT: Gamma-glutamyl transferase; TSH: Thyroid-stimulating hormone. 
and is preferred in patients with comorbidities as it can be applied quickly, is a simple method and is associated with low morbidity rates. ${ }^{[4]}$ Natural gastrointestinal integrity is preserved in SG and no malabsorption is seen. Furthermore, it can be converted to other bariatric surgical procedures if necessary ${ }^{[5]}$ Although bariatric surgery is the most commonly performed procedure at the present time, its side effects and long-term outcomes are not known well.

The mechanism of action of SG in weight loss does not depend solely on the restrictive mechanism. The removal of the gastric fundus during the operation was found to reduce the hormone level secreted by the fundus ghrelin ${ }^{[1]}$ and insulin secretion through pancreatic beta-cell apoptosis. ${ }^{[2]}$ It has been further seen to increase GLP-1 levels and insulin secretion, to reduce glucagon production and glucose production from the liver and to have, therefore, beneficial effects on glucose metabolism. ${ }^{[3]}$ Sleeve gastrectomy has been understood to have not only mechanical effects but also to cause many metabolic changes. This has led to the necessity of examining a series of metabolic changes in the patient and laboratory results in the postoperative period.

It has been further shown that even if the body mass index (BMI) is the same, there are significant differences between women and men in terms of body fat metabolism. ${ }^{[6]}$ An increase is known to occur in fecal excretion of unesterified fatty acids and bile acids due to $\mathrm{SG}^{\left[{ }^{[7]}\right.}$

Non-alcoholic fatty liver disease develops as a result of excessive accumulation of triglycerides in the liver. The presence of liver cell damage and inflammation in addition to the accumulation of fat is defined as nonalcoholic steatohepatitis (NASH). ${ }^{[8]}$ In a comprehensive systematic review on steatohepatitis, many studies in this area have reported that the incidence of steatohepatitis in men is higher than in women ${ }^{[9,10]}$ and aminotransferase enzyme levels are also higher in men. However, the female gender has been suggested to be associated with steatohepatitis only in a few studies. ${ }^{[11-13]}$

In a study examining the relationship between liver fat and gender, the rate of steatohepatitis and serum AST, ALT and GGT levels were found to be higher in men than in women. ${ }^{[14]}$ Considering these findings, it should be clarified what is the reason for the higher AST and ALT levels in male patients in the present study; whether it is a gender-based change or a metabolic differentiation triggered after SG.
Gender was found to be not an effective factor for free T3 and free T4 values in a study where the relationship between gender and these values was investigated. ${ }^{[15]}$ The high levels of free T3 in male patients in the present study can be attributed to the metabolic processes triggered after SG.

With the acceleration of gastric emptying, nutrients reach the intestines quickly and the sense of satiety is achieved more quickly thanks to the neuroendocrine hormones secreted from here, and metabolism changes and re-regulates blood sugar and cholesterol levels. ${ }^{[16]}$ In SG, the undigested food reaches the small intestine very quickly from the stomach and then, to the distal part of the small intestine. Undigested food that reaches the distal part of the small intestine stimulates the intestinal cells, causing GLP-1 and many other incretins to be released. Insulin resistance and glucose metabolism are regulated by these released hormones and incretins. It also stimulates insulin secretion from the pancreas. ${ }^{[17]}$ In a study by Li et al., ${ }^{[18]}$ it was observed that lipid and glycogen content in the liver decreased and metabolic symptoms improved in obese mice undergoing SG. The possible cause of these changes has been thought to be the differentiation of hypothalamic neuronal populations.

In a study, where biochemical analysis of obese patients undergoing SG and non-surgical medical treatments was performed, pre- and post-operative biochemical analysis results of patients were compared and BMI, AST, ALT, triglyceride, and HgA1c levels were found to be statistically significantly lower in SG group than the group receiving non-surgical treatment, however, HDL levels of SG group was found to be significantly higher. ${ }^{[19]}$

In the literature, it has been suggested that deficiency in thyroid hormone secretion would lead to weight gain. Indeed, some weight gain has been observed in hypothyroid cases, however, less than $10 \%$ of individuals with obesity have hypothyroidism. This rate is much less in individuals with morbid obesity. ${ }^{[20]}$ Thyroid hormones of such individuals are generally within normal limits, but a positive correlation has been observed between TSH and BMI. In studies, TSH was found to be slightly higher in obese individuals compared to individuals with normal weight. ${ }^{[21]}$

Similarly, in a study conducted in Turkey, TSH levels were found to be significantly higher in obese patients compared to the control group and free T3 levels in severe obesity patients were found to be higher than patients with mild to moderate obesity and control group. ${ }^{[22]}$ 
In a study, Nader et al. ${ }^{[23]}$ examined 20 overweight and 30 obese children in terms of TSH levels and found no significant difference between the two groups in this regard. In the same study, the authors reported that there was no difference between the degree of obesity and TSH levels. Similarly, Mutlu et al. ${ }^{[24]}$ found no significant difference between obese patients and the control group in terms of TSH and free T4 levels in their study.

In the present study, postoperative AST, ALT, GGT, and free T3 levels were found to be higher in men than in women. There is limited number of studies in this area and further studies are needed to identify metabolic changes in patients undergoing SG.

\section{Disclosures}

Peer-review: Externally peer-reviewed.

Conflict of Interest: None declared.

\section{References}

1. Kalinowski P, Paluszkiewicz R, Wróblewski T, Remiszewski P, Grodzicki M, Bartoszewicz, et al. Ghrelin, leptin, and glycemic control after sleeve gastrectomy versus Roux-en-Y gastric bypass-results of a randomized clinical trial. Surg Obes Relat Dis 2017;13:181-8. [CrossRef]

2. Méndez-Giménez $L$, Becerril $S$, Camões $S P$, da Silva IV, Rodrigues $C$, Moncada R, et al. Role of aquaporin-7 in ghrelinand GLP-1-induced improvement of pancreatic $\beta$-cell function after sleeve gastrectomy in obese rats. Int J Obes (Lond) 2017;41:1394-402. [CrossRef]

3. Benaiges D, Más-Lorenzo A, Goday A, Ramon JM, Chillarón JJ, Pedro-Botet J, et al. Laparoscopic sleeve gastrectomy: More than a restrictive bariatric surgery procedure? World J Gastroenterol 2015;21:11804-14. [CrossRef]

4. Magee CJ, Barry J, Arumugasamy M, Javed S, Macadam R, Kerrigan DD. Laparoscopic Sleeve Gastrectomy For HighRisk Patients: Weight Loss And Comorbidity İmprovement-Short-Term Results. Obes Surg 2011;21:547-50. [CrossRef]

5. Anuk T, Köksal N, Avşar F, Allahverdi TD, Sülü B, Çakmur H. Our İnitial Results Related To Bariatric Surgery. Ege Journal Of Medicine 2017;56:82-5. [CrossRef]

6. Blaak E. Gender differences in fat metabolism. Curr Opin Clin Nutr Metab Care 2001;4:499-502. [CrossRef]

7. Uzdil Z, Saka M Bariatrik Cerrahi Uygulamalarının Mikrobiyota Üzerine Etkilerinin Değerlendirilmesi. Gazi Üniversitesi Sağlık Bilimleri Dergisi 2018:1:38-44.

8. Aksoy EK, Göktaş Z, Albuz Ö, Akpınar MY, Öztürk D, Buluş H, et al. Sleeve Gastrektomi Uygulanan Hastalarda Ağırlık Kaybının Nonalkolik Yağıı Karaciğerile İlgili Bazı Yeni Parametreler Üzerine Etkisi. Bes Diy Derg 2018;46(3):240-7. [CrossRef]

9. Chen ZW, Chen LY, Dai HL, Chen JH, Fang LZ. Relationship
Between Alanine Aminotransferase Levels And Metabolic Syndrome in Nonalcoholic Fatty Liver Disease. J Zhejiang Univ Sci B 2008;9:616-22. [CrossRef]

10. Sorrentino $P$, Tarantino G, Conca P, Perrella A, Terracciano ML, Vecchione R, et al. Silent Non-Alcoholic Fatty Liver Disease-A Clinical-Histological Study. J Hepatol 2004;41:751-7.

11. Hashimoto E, Yatsuji S, Kaneda H, Yoshioka Y, Taniai M, Tokushige $\mathrm{K}$, et al. The Characteristics And Natural History Of Japanese Patients With Nonalcoholic Fatty Liver Disease. Hepatol Res 2005;33:72-6. [CrossRef]

12. Ong JP, Elariny $H$, Collantes $R$, Younoszai $A$, Chandhoke $V$, Reines HD, et al. Predictors Of Nonalcoholic Steatohepatitis And Advanced Fibrosis In Morbidly Obese Patients. Obes Surg 2005;15:310-5. [CrossRef]

13. Vernon G, Baranova A, Younossi ZM. Systematic review: the epidemiology and natural history of non-alcoholic fatty liver disease and non-alcoholic steatohepatitis in adults. Aliment Pharmacol Ther 2011;34:274-85. [CrossRef]

14. Kim HJ, Lim CW, Lee JH, Park HB, Suh $Y$, Cho $Y H$, et al. Gender-Based Differences İn The Relationship Between Fatty Liver Disease And Atherosclerosis. Cardiovasc J Afr 2016;27:281-6. [CrossRef]

15. Abbas R, Abbas HG, Shahid A, Chand S, Nawaz S. Reference İntervals For Free T3 And Free T4 İn Pakistani Euthyroid Patients: Effect Of Age Andgender On Thyroid Function. J Coll Physicians Surg Pak 2014;24:806-9.

16. Hady HR, Dadan J, Gołaszewski P, Safiejko K. Impact Of Laparoscopic Sleeve Gastrectomy On Body Mass Index, Ghrelin, İnsulin And Lipid Levels In 100 Obese Patients. Wideochir Inne Tech Maloinwazyjne 2012;7:251-9. [CrossRef]

17. Bužga $M$, Holéczy $P$, Svagera Z, Svorc $P$ Jr, Zavadilová V. Effects Of Sleeve Gastrectomy On Parameters Of Lipid And Glucose Metabolism İ Obese Women - 6 Months After Operation. Wideochir Inne Tech Maloinwazyjne 2013;8:22-8.

18. Li P, Rao Z, Laing B, Bunner WP, Landry T, Prete A, et al. Vertical sleeve gastrectomy improves liver and hypothalamic functions in obese mice. [Epub ahead of print] $\mathrm{J}$ Endocrinol 2019. pii: JOE-18-0658.R2. [CrossRef]

19. Ohira M, Yamaguchi T, Saiki A, Nakamura S, Tanaka S, Oka $\mathrm{R}$, et al. Laparoscopic Sleeve Gastrectomy Significantly Increases Serum Lipoprotein Lipase Level İn Obese Patients. Obes Facts 2019;12:357-68. [CrossRef]

20. Altunoğlu E, Ülgen E, Müderrisoğlu C, Erdenen F, Boz M. Obezite Ve Tiroid Fonksiyonları. Istanbul Med J 2011;12:69-71.

21. Reinehr T. Obesity And Thyroid Function. Mol Cell Endocrinol 2010;316:165-71. [CrossRef]

22. Boyraz M. Çocuklarda Obezite ve Tiroid Fonksiyon Testleri İlişkisi. Yeni Tıp Dergisi 2013;30:160-3.

23. Nader NS, Bahn RS, Johnson MD, Weaver AL, Singh R, Kumar S. Relationships Between Thyroid Function And Lipid Status Or İn-Sulin Resistance İ A Pediatric Population. Thyroid 2010;20:1333-9. [CrossRef]

24. Mutlu G, Özsu E, Çizmecioğlu F, Hatun Ş. Şişman Çocuklarda Hafıf TSH Yüksekliği: Nasıl Bir Sorun?, Türk Pediatri Ars 2011;46:33-6. [CrossRef] 